\title{
Ipomoea fulvicaulis (Convolvulaceae), a new record for India
}

\author{
Kattee A.V. ${ }^{1}$, Dalavi J.V. ${ }^{2}$, Patil C.R. ${ }^{3}$ \& V.B. Shimpale ${ }^{1 *}$ \\ ${ }^{1}$ Department of Botany, The New College, Kolhapur District, Maharashtra-416 012, India. \\ 2Department of Botany, Shivaji University, Kolhapur District, Maharashtra-416 004, India. \\ ${ }^{3}$ Department of Botany, D.K.A.S.C. College, Ichalkaranji, Kolhapur District, Maharashtra-416 115, India. \\ *E-mail: shimpale@yahoo.com
}

\begin{abstract}
Ipomoea fulvicaulis (Hochst. ex Choisy) Boiss. ex Hallier f. (Convolvulaceae), recently collected from Nandi hills of Karnataka state, is reported here as a new record for the flora of India. A detailed taxonomic account, including description, illustrations and photographs are provided to facilitate easy identification.
\end{abstract}

Keywords: Ipomoea fulvicaulis, Karnataka, New Record.

\section{INTRODUCTION}

Ipomoea L. is the largest and widely distributed genus of the family Convolvulaceae. Worldwide the genus is represented by 650 species having high distributional range in the tropical and sub-tropical regions (Mabberley, 2017). In India the genus is represented by c. 63 species (Shimpale et al., 2014) with 4 endemic taxa (Singh et al., 2015). During a taxonomic revision of the genus Ipomoea for India, the authors collected some interesting specimens from Nandi hills of Chikkaballapur District, Karnataka State of Peninsular India. After critical examination of specimens, scrutiny of relevant literature (Clarke, 1883; Cooke, 1905; Verdcourt, 1963; Johari, 1983; Goncalves, 1987; Biju, 1997; Hyde \& Wursten, 2011; Wood et. al., 2015) and consultation of protologues and types, it was identified as I. fulvicaulis (Hochst. ex Choisy) Boiss. ex Hallier f., a species reported previously from Tropical East Africa, Botswana, Ethiopia, Malawi, Mozambique, Zambia and Zimbabwe. This taxon is so far not reported from Indian subcontinent and therefore it forms a new distributional record for the flora of India. The species is morphologically close

Received: 29.06.2018; Revised \& Accepted: 08.09.2019 Published Online: 30.09.2019 to I. barlerioides (Choisy) Benth. ex C.B. Clarke in having perennial habit, prostrate or twining hirsute stems and ovate-oblong, hairy leaves but differs from it in having short peduncle $(0.5-0.7 \mathrm{~cm}$ long), sessile to sub-sessile flowers, $3-3.5 \mathrm{~cm}$ long corolla and summer flowering against long peduncles (3-8 $\mathrm{cm}$ long), distinctly pedicellate flowers, $5-6 \mathrm{~cm}$ long corolla and monsoon flowering in I. barlerioides (Table-1). A detailed description, illustrations and relevant notes are provided to facilitate easy recognition of this species in the field.

Ipomoea fulvicaulis (Hochst. ex Choisy) Boiss. ex Hallier f., Bot. Jahrb. Syst. 18(1-2): 128. 1893; Verdc., Fl. Trop. E. Africa. 1: 97. 1963; Goncalves, Flora Zambesiaca 8(1): 9. 1987; Chapano \& Mugarisanwa, Pl. Matobo District, Zimbabwe 22. 2003. Aniseia fulvicaulis Hochst. ex Choisy Prodr. DC., 9: 431. 1845. Type: ETHIOPIA, Abessinia, 12.01.1893, W. Schimper 270 (iso GOET005696 digital image!)

Figs. 1 \& 2.

Perennial herbs with woody rootstock. Stems slender, spreading, much branched, up to $1 \mathrm{~m}$ long, brownish pubescent. Leaves oblong to ellipticovate, $2-3 \times 1.5-2 \mathrm{~cm}$, oblong to emarginate at apex, entire, cordate to truncate at base, densely pubescent on both surfaces, sparsely pubescent at maturity; petioles 1-2 cm long, densely pubescent. Inflorescences cymose; peduncles c. $0.8 \mathrm{~cm}$ long, hairy; bracts ovate, $0.5-0.6 \times 0.4-0.5 \mathrm{~cm}$, acuminate, hairy out, glabrous in, pink. Flowers sessile or sub-sessile. Sepals 5 , unequal, outer 2 ovate, $1.5-1.7 \times 0.6-0.7 \mathrm{~cm}$, middle 1 lanceolate, $1.5-1.6 \times 0.5-0.6 \mathrm{~cm}$, inner 2 linear, $1.5-1.6 \times$ $0.2-0.4 \mathrm{~cm}$, bristly hairy out, glabrous in. Corolla funnel-shaped, $3-3.5 \mathrm{~cm}$ long, pink; tube $2-2.5 \mathrm{~cm}$ long, pubescent out, glabrous in; lobes $1.2-1.5 \mathrm{~cm}$ 


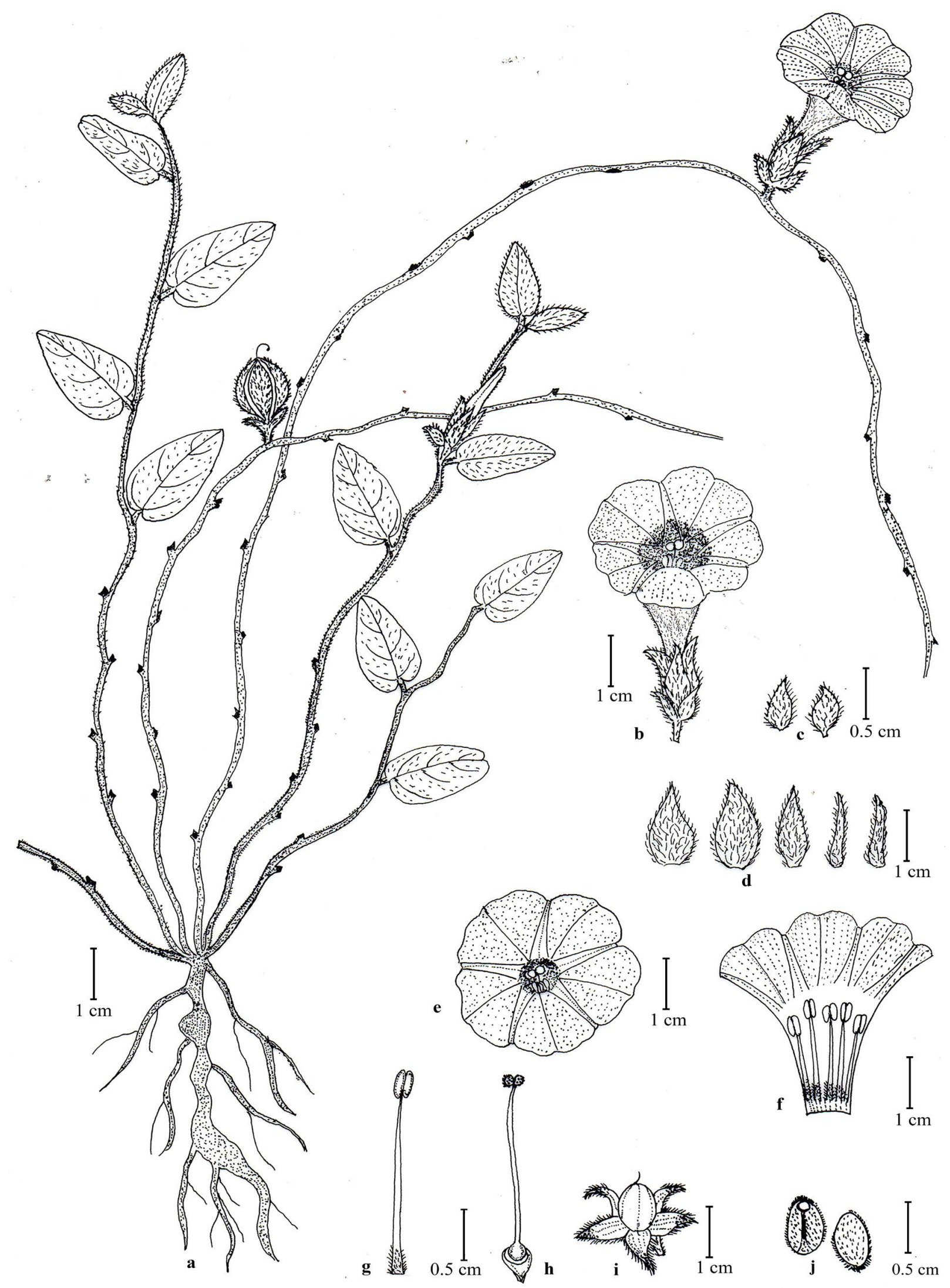

Fig. 1. Ipomoea fulvicaulis (Hochst. ex Choisy) Boiss. ex Hallier f.: a. Habit; b. Flower; c. Bracts; d. Sepals; e. Corolla top view open; f. Corolla split open; g. Stamen; h. Gynoecium; i. Capsule; j. Seeds. 


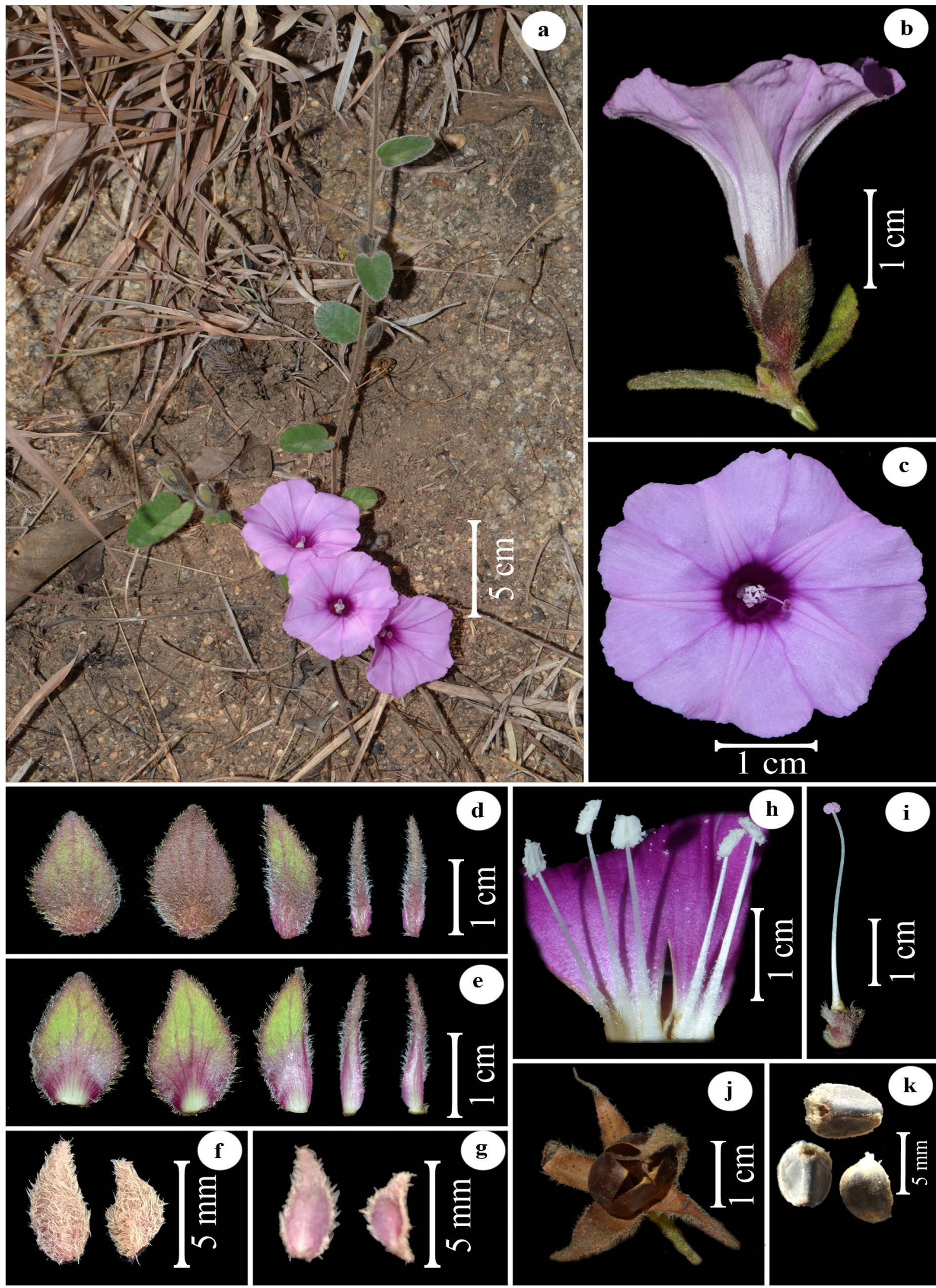

Fig. 2. Ipomoea fulvicaulis (Hochst. ex Choisy) Boiss. ex Hallier f.: a. Habit; b. Flower; c. Flower top view; d. Sepals-abaxial view; e. Sepals-adaxial view; f. Bracts-abaxial view; g. Bracts-adaxial view; h. Dissected corolla showing stamens; i. Gynoecium; j. Capsule; k. Seeds. 
Table 1. Taxonomic differences between I. barleriodes and I. fulvicaulis

\begin{tabular}{|l|l|l|}
\hline Characters & $\begin{array}{l}\text { Ipomoea barlerioides (Choisy) Benth. } \\
\text { ex C.B. Clarke }\end{array}$ & $\begin{array}{l}\text { Ipomoea fulvicaulis (Hochst. ex Choisy) Boiss. ex } \\
\text { Hallier f. }\end{array}$ \\
\hline Peduncle & $3-8 \mathrm{~cm}$ long & $0.5-0.8 \mathrm{~cm}$ long \\
\hline Pedicel & $0.6-1.2 \mathrm{~cm}$ long & Absent or $0.2 \mathrm{~cm}$ long \\
\hline Corolla & $6-8 \mathrm{~cm}$ long & $3-3.5 \mathrm{~cm}$ long \\
\hline Stamens & $\begin{array}{l}\text { Filaments attached up to mouth of } \\
\text { corolla tube }\end{array}$ & Filaments attached only at base of corolla tube \\
\hline Seeds & $0.8-1.2 \times 0.6-0.8 \mathrm{~cm}$ & $0.5-0.7 \times 0.4-0.5 \mathrm{~cm}$ \\
\hline Phenology & September to November & January to March \\
\hline
\end{tabular}

long, pink. Stamens sub-equal; filaments included, $1.7-2 \mathrm{~cm}$ long, attached to the base of corolla tube, hairy at base; anthers 2-celled, dehiscing longitudinally; pollen grains globular, pantoporate, echinate. Carpels 2, fused; ovary ovoid, glabrous, $c$. $0.2 \times 0.1 \mathrm{~cm}$; style $2.8-3 \mathrm{~cm}$ long; stigma bi-lobed, slightly exserted, pink. Capsules globose, 0.8-1.2 $\times$ 0.5-0.9 cm, glabrous, brown. Seeds ovoid, 0.5-0.7 $\times 0.4-0.5 \mathrm{~cm}$, brown pubescent, hairy at margins.

Flowering \& fruiting: January-March.

Habitat: In rocky crevices at elevation of 1380 to $1420 \mathrm{~m}$, mostly associated with Cymbopogon martini (Roxb.) Watson, Crotalaria albida B.Heyne ex Roth var. kangrensis Ansari, Shorea roxburghii Don, Indigofera mysorensis Rottler ex DC and Aristida setacea Retz.

Distribution: East Tropical Africa, Botswana, Ethiopia, Malawi, Mozambique, Zambia, Zimbabwe (Hilliard, 1983) and now in India.

Specimens examined: INDIA, Karnataka, Chikkaballapur district, Nandi Hills, $13^{\circ} 21^{\prime} 32.796^{\prime \prime} \mathrm{N}, 7^{\circ} 40^{\prime} 35.22^{\prime \prime} \mathrm{E}, 03.03 .2019$, Kattee, Shimpale \& Dalavi AVK14 (SUK!). Tamil Nadu, Tirunelveli district, Kalkkad (Kalakkad), 16.02.1913, D. Hooper \& M.S. Ramaswami 311430 (CAL!).

Notes: The species is rare, c. 50 individuals were located in the Nandi hills. It was also collected previously by Hooper and Ramaswami in 1913 from Kalakkad, Tirunelveli district of Tamil Nadu state but misidentified as Ipomoea barlerioides (Choisy) Benth. ex C.B. Clarke. The population from Nandi Hills shows some variations from the protologue like short peduncle, ovate bracts and tubular funnel-shaped corolla but these variations may be due to the change in the habitat.

\section{Acknowledgements}

Authors are thankful to Principal, The New College, Kolhapur and Head, Department of Botany Shivaji University, Kolhapur for facilities; the Director, Botanical Survey of India, Kolkata for herbarium consultation. AVK is thankful to Babasaheb Ambedkar Research and Training Institute, Pune for fellowship. JVD is thankful to Ministry of Environment forest and Climate Change (MoEF \& CC) for financial assistance (No. 40084 dated 16.11.2016).

\section{Literature Cited}

BIJU S.D. 1997. Taxonomic and morphological studies in family Convolvulaceae of southern Peninsular India. Submitted to University of Calicut (Unpublished).

CLARKE C.B. 1883. Convolvulaceae. In: HOOKER J.D. (Ed.), Flora of British India. Volume 4. L. Reeve \& Co., London. pp. 196-216.

COOKE T. 1905. The Flora of the Presidency of Bombay. Volume 2. Taylor \& Francis, London. p. 261.

GONCALVES M.L. 1987. Convolvulaceae. In: LAUNET E. (Ed.), Flora Zambesiaca. Volume 8(1). Royal Botanic Garden, Kew. pp. 68-69.

HILLIARD O.M. 1983. Convolvulaceae. In: GERMISHUIZEN G. (Ed.), Flora of southern Africa. Botanical Research Institute, South Africa. p. 85.

HYDE M.A. \& B. WURSTEN. 2011. Flora of Zimbabwe. Available from http://www.zimbanweflora.co.zw (accessed on 05.04.2019).

JOHARI S.C. 1983. Genus Ipomoea L. in India. Submitted to University of Rajasthan (Unpublished).

MABBERLEY D.J. 2017. Mabberley's Plant-Book: A portable dictionary of plants, their classification and uses. Fourth Edition. Cambridge University Press, Cambridge. pp. 
466-467.

SHIMPALE V.B., KARE M.A., LONDHE D.K. \& A.S. BHUKTAR 2014. On the occurrence of Ipomoea tenuipes (Convolvulaceae) in India. Rheedea 24(2): 117-119.

SINGH P., KARTHIGEYAN K., LAKSHMINARASIMHAN

P. \& S.S. DASH 2015. Endemic Vascular Plants of India. Botanical Survey of India, Kolkata. p.144.
VERDCOURT B. 1963. Convolvulaceae. In: HUTCHINSON J. \& M.J. DALZIEL (Eds.), Flora of Tropical East Africa. Volume 2(1). Royal Botanic Garden, Kew. pp. 208-219.

WOOD J.R.I., CARINE M.A., HARRIS D., WIKIN P., WILLIAMS B. \& R.W. SCOTLAND 2015. Ipomoea (Convolvulaceae) in Bolivia. Kew Bulletin 70 (31): 1-124. 